\title{
İhsan Oktay Anar'ın Kitab-ül Hiyel adlı eserinin İngilizce çevirisindeki (The Book of Devices) özel isimler ve çeviri stratejileri üzerine karşılaştırmalı bir inceleme
}

\section{Aslı ARABOĞLU1}

\begin{abstract}
APA: Araboğlu, A. (2020). İhsan Oktay Anar'ın Kitab-ül Hiyel adlı eserinin İngilizce çevirisindeki (The Book of Devices) özel isimler ve çeviri stratejileri üzerine karşılaştırmalı bir inceleme. RumeliDE Dil ve Edebiyat Araşttrmaları Dergisi, (18), 699-708. DOI: 10.29000/rumelide.706494
\end{abstract}

\section{Öz}

İhsan Oktay Anar ikinci kitabı "Kitab-ül Hiyel” ile Türk edebiyatının son dönemlerinin postmodern ve fantastik roman yazarlarından biri olarak kabul edilmektedir. Hayali karakterleri, tarihsel çağrışımlarla kurgulanan olayları, gerçek dışı kurguları ve kültürel öğeleri barındıran bu tür eserlerin çeviri sürecinde çevirmenler çeşitli çeviri sorunlarıla karşlaşabilmektedir. Bu tür sorunların üstesinden gelebilmek için çeviriye dair farklı yaklaşımlar bulunmaktadır. Özellikle kültürel çeviriler bağlamında özel isimlerin çevirisi, çevirmenler açısından oldukça meşakkatli bir hal almaktadır. Bu çalışmada İhsan Oktay Anar' ın “Kitab-ül Hiyel” adlı eseri ve İngilizce çevirisi karşılaştırılacak, özel isimlerin İngilizce’ ye nasıl çevrildiği incelenecek ve Eirlys Davies in (2003) kültürel öğeler ve özel isimlerin çevirisi için sunmuş olduğu görüşler çerçevesinde çevirmen tarafından kullanılan çeviri stratejileri tespit edilecektir. Aynı zamanda çeviri stratejileri Javier Franco Aixela'nın (1996) Kültürel Öğelerin Çevirisi için sunduğu sınıflandırma ile irdelenecek ve ardından çevirmenin temel çeviri eğilimi saptanacaktır. Bunun yanı sıra Theo Hermans'ın (1988) özel isimlerin metindeki görevlerine ve bu bağlamda çevrilmesine yönelik sunduğu ikili kategoriden çalışmanın sonuç kısmında faydalanılacaktır. Bu çalışmanın amacı kültürel çeviri bağlamında, eserde yer alan Türkçeye özgü kültürel ifadeler ile oluşturulan özel isimlerin İngilizce çevirilerine nasıl çözümler bulunduğunu tespit etmektir. Bu çalışmada, çevirmenin çoğunlukla kaynak metindeki sözcüklerin gerçek anlamlarını açıklamaya yönelik ve bu şekilde erek okurun metni daha iyi anlamasını amaçlayan, çeviri stratejileri kullandığı düşünülmektedir.

Anahtar kelimeler: Özel isimlerin çevirisi, kültürel çeviri, İhsan Oktay Anar, fantastik edebiyat çevirisi.

\section{A comparative analysis on proper names and their translation strategies in English translation of Kitab-ül Hiyel (The Book of Devices) by İhsan Oktay Anar}

\begin{abstract}
İhsan Oktay Anar is considered to be one of the postmodern and fantastic novel writers of the last period of Turkish literature with his second book "Kitab-ül Hiyel". In the translation process of these works, which include imaginary characters, historical fictions and cultural elements, translators may encounter various translation problems and there are different approaches to their translation. The translation of proper names, especially in the context of cultural translation, is very challenging for translators. In this study, İhsan Oktay Anar's "Kitab-ül Hiyel” and its English translation will be
\end{abstract}

1 Dr. Öğr. Üyesi, Trakya Üniversitesi, Edebiyat Fakültesi, Mütercim Tercümanlık Bölümü (Edirne, Türkiye), ozenasli@hotmail.com, ORCID ID: 0ooo-0oo1-6910-5706 [Makale kayt tarihi: 07.11.2019-kabul tarihi: 20.03.2020; DOI: $10.29000 /$ rumelide.706494] 
A comparative analysis on proper names and their translation strategies in English translation of Kitab-ül Hiyel (The Book of Devices) by İhsan Oktay Anar / A. Araboğlu (pp. 699-708)

\begin{abstract}
compared, the translation of proper names into English will be examined and the translation strategies used by the translator within the framework of Eirlys Davies Davies' views on cultural elements and the translation of specific names will be determined. Then, the translation strategies used will be handled by Javier Franco Aixela's (1996) classification for the translation of cultural elements and main translation tendency of the translator will be determined. Theo Hermans's (1988) dual category for the translation of proper names and their translations in this context will be utilized in the conclusion part. Thus, the aim of this study is to find out how to find solutions to English translations of proper names created with cultural expressions in Turkish in the context of cultural translation. At this study, it's thought that the translator has mostly used translation strategies, which are aimed to explain the denotative meaning of words in the source text and thus aiming the target reader to understand the text better.
\end{abstract}

Keywords: Translation of proper names, cultural translation, İhsan Oktay Anar, translation of fantasy literature.

\title{
1. Giriş
}

Bu makalenin amacı, fantastik roman olarak kabul edilen İhsan Oktay Anar' in "Kitab-ül Hiyel” adlı eserinde yer alan tarihsel ve kurgusal özel isimlerin nasıl çevrildiğini incelemektir. İnceleme esnasında kaynak metinde yer alan özel isimler erek metinle karşlaştırılacak, çevirmen kararları irdelenecektir. İdelemeye neden olan temel sorunsal, çoğunlukla İngilizceden Türkçeye yapılan fantastik eser çevirilerinin dışında ters yönde Türkçeden İngilizceye çevrilen fantastik ya da bilim kurgu türündeki eserlerde, yazar tarafından türetilen özel isimlerin ve çevirilerinin incelenmesine yönelik araştırmaların çeviribilim alanında yeterli sayıda yapılmamış olmasıdır. Çeviribilim alanında, çevirmen kararları, çevirmenin metni yeniden oluştururken kullandığı stratejiler, meşakkatli durumlarla baş edebilmek için bulduğu çözümler büyük önem arz etmektedir. Bu nedenle bu makalenin inceleme nesnesini, İhsan Oktay Anar' in "Kitab-ül Hiyel” adlı eseri ve çevirisi oluşturacak ve yazar tarafından türetilen özel isimlerin çevirisi incelenecektir.

Bilim Kurgu ve Fantastik Edebiyat türü son dönemlerde oldukça popüler olmasıyla daha fazla okunur hale gelmiştir. Sadece yazıldığı dillerde değil, benzer şekilde, çevrildiği dillerde de özgün eserler kadar okunmakta ve edebiyat dizgesini şekillendirmektedir. Gerçeğin ötesinde, mitolojik hikâyeler, tarihsel olaylar ve tüm fantezi dünyamızla şekillenen bu kurgusal edebiyat sayesinde okuyucular birçok metinlerarası göndermeyi izleyerek kendi kurgusal dünyalarını keşfetmektedirler. Bahsi geçen özellikler göz önünde bulundurulduğunda, yazarın üslubunun ve yaratıcı özelliğinin ön planda olduğu bu tür eserlerin çevirisi de çevirmeni oldukça meşakkatli bir duruma sokmaktadır. Çevirmen, bir yandan yazarın fantastik kurgu dünyasında ne dediğini eksiksiz anlayacak bir yandan da çeviri sayesinde metni erek okura ulaştırabilmek için eseri tekrar oluşturacaktır. Bilim Kurgu ve Fantastik Edebiyat türlerinde çoğunlukla yaratıcı yazınla beraber yazarın türettiği yeni sözcüklerle de karşılaşılmaktadır. Bu durumda türetilen sözcüklerin çevirisi de farklı çevirmen kararlarıyla karşımıza çıkmaktadır. Fantastik ve bilim kurgu eserlerinin çevirisi konusunda çeviribilim alanında yapılan birçok çalışma bulunmaktadır. Bu çalışmaların içinde, 2006 yılında İstanbul Üniversitesi Edebiyat Fakültesi İngiliz Dili ve Edebiyatı Anabilim Dalı ev sahipliğinde gerçekleşen "Akşit Göktürk'ü Anma Toplantısı: Yazında ve Çeviride Fantastik” oldukça dikkat çekicidir. Osmanlı'da ve Cumhuriyet tarihinde fantastik eserlerin 
edebiyatımıza nasıl kazandırıldığının yanı sıra, uygulama safhasında çevirmenlerin hangi kararlarla nasıl karşımıza çıktığına farklı bilimsel çalışmalarla değinilmiştir. ${ }^{2}$

$\mathrm{Bu}$ çalışmanın inceleme nesnesini oluşturan, değişik dönemlerden tarihi olayları konu edindiği ve anlatılanların çoğu tarihi gerçeklere dayandığı için tarih romanı olarak adlandırılabilecek "Kitab-ül Hiyel'in, olayların gerçek ve bilinen bir dünyanın ötesinde yazarın hayal gücüne dayalı bir dünyada anlatılması yönüyle fantastik roman özellikleri taşıdığı söylenebilir. Servet Şengül, Karlıdağ’dan aktararak, romanın tarihteki nesnel gerçekliğin peşinde olmak yerine tarihin kendisinin kurmaca olduğu düşüncesinden hareket etmesi nedeniyle eserin bir palimpsest 3 roman olarak kabul edilebileceğini söylemektedir. Şengül'e göre "Kitab-ül Hiyel”in palimpsest bir roman olarak kabul edilmesi gerektiğinin bir diğer nedeni de bu tür romanlarda - resmi tarih çizgisinin dışına çıkarak alternatif bir tarih üretilmesi ve tarihe farklı bir yorum getirilmesidir (Şengül, 2018, s. 92). Kaynak metinde yer alan anlatımın kurgusallığını tarihten bağımsız olarak düşünmek mümkün görünmemektedir. Yazar tarafından türetilen özel isimlerin oluşturulmasında da tarihi göndermeler ve eski Türkçe sözcük yapıları mevcuttur. Romanda geçen karakterler padişahlar, devlet adamları, âlimler, dini ve mitolojik şahıslardan oluşmakta ve art arda getirilmiş siyasi, ilmi, askeri ve toplumsal anlamlar taşıyan sözcüklerden türetilen özel isimler almaktadır. Bu isimler aslında karakterlerin kendilerini tanımlamaktadır. Bahsi geçen özel isimlerin çevirisi ise oldukça zorlu olabilmektedir. Kaynak metinde yer alan isimlerin sahip olduğu işlevi çeviri metinde de kazandırabilmek için çevirmen farklı stratejiler tercih edebilir ve belirli bir çeviri eğilimi yeğleyebilir. Bu çalışmada kaynak metin ve erek metin incelendikten sonra kaynak metinde yer alan özel isimler (karakterler) tespit edilecek, çevirmenin eserde karakterlere verilen özel isimleri nasıl çevirdiği üzerinde durulacaktır. Ardından çevirmenin genel çeviri eğilimi tespit edilecektir. Eserde yer alan görsellerin çevirisinde kullanılan stratejilerin de genel çeviri eğilimini tespit etmede katkısı olacağı düşünülmektedir.

\section{Kitab-ül Hiyel}

İhsan Oktay Anar’ın “Kitab-ül Hiyel, Eski Zaman Mucitlerinin İnanılmaz Hayat Öyküleri” adlı romanı Kuran'dan ve 1. Samuel'den alıntılarla başlamakta ve Yasef Çelebi, Calûd ve Üzeyir Bey olmak üzere üç nesil mucidin hayat öyküsüne yer vermektedir. Lalezar Necef Bey, Uzun İhsan Efendi, Samur ve Yağmur Çelebiler gibi ilginç karakterler mucit, hiyelkar, aktarıcı, meyhaneci, kahveci gibi kimliklerle karşımıza çıkmaktadır. Üç bölümün her birinde ilgili mucidin yaşadıkları başkalarından aktarılarak anlatılır. Hırs ve zekânın ürünü icatların çizimlerinin de kitapta yer alması mucitleri icatlarıyla daha anlaşılır hale getirmektedir. Diğer yandan Vaka-yı Hayriye ve Gülhane Hatt-ı Hümayunu gibi tarihsel olayların ve Sultan Selim-i Salis Han ve Sultan Abdülhamid Han gibi Sultanların isimlerinin de eserde yer alması okura anlatının hangi zaman diliminde geçtiğine dair bilgiler vermektedir. "Tamburlu kıraathane eşrafından Divane Salim Efendi ile Tiryaki Fülfül Çelebi” gibi anlatıda geçen isimler ise sadece karakter olarak kalmamakta aynı zamanda yaptıkları meslekler, konumları, sosyolojik bağları hakkında da bize bilgi vermektedir. Doksandan fazla farklı meslek ve erbaptan karakterin bir araya gelerek metinde yer almasıyla, her birinin ana karakterler kadar aktaran kişiler olarak da olay örgüsünü oluşturmada önemli

$2 \quad$ Akşit Göktürk’ü Anma Toplantısı: Yazında ve Çeviride Fantastik. İstanbul: İstanbul Üniversitesi Rektörlüğü, 2006.

3 Kubilay Aktulum Metinlerarası İlişkiler adlı kitabında metinlerarasılığın bir türü olarak bu kavrama yer verir. Aktulum'a göre her yapıt metinlerarasıdır ve her eser kendinden önce yazllanın izlerini taşır. "Palimpsest" gerçek anlamından hareketle metaforik bir anlam taşımaktadır; bir metnin kazınarak yaprağın üzerine yeni bir metin eklendiği ancak eski metnin tümüyle gizlenemediği ve eski metnin de görülebildiği bir göndermedir. "Ortak kanıya göre, eski bir yazar 'ilk kez’ yazmış, ardından başka bir yazar (çoğu zaman bir taklitçi ya da kopyacı diye anılan) yeni bir metnin sayfalarını bir başka türlü yeniden yazmıştır” (Aktulum, 1999, s.217) 
A comparative analysis on proper names and their translation strategies in English translation of Kitab-ül Hiyel (The Book of Devices) by İhsan Oktay Anar / A. Araboğlu (pp. 699-708)

bir yere sahip olduğu söylenebilir. İlk baskısı İletişim Yayınları tarafından 1996 yılında yapılan eserin 2018 yılında çıkan 30. baskısı bu çalışmadaki incelemelerde kaynak metin olarak kullanılmıştır.

\section{The Book of Devices}

Kitab-ül Hiyel'in İngilizce çevirisi Binghamton Üniversitesi Türk Dili Profesörü Gregory Key tarafından 2016 yılında Türkiye Cumhuriyeti Kültür ve Turizm Bakanlığı ve TEDA projesinin ${ }^{4}$ desteğiyle yapılmıştır. Bu çalışmada çevirilerin karşılaştırılması amacıyla kullanılan erek metin Koç Üniversitesi Yayınlarından çıkan 2018 yılı basımıdır. Eser "The Book of Devices, The incredible life histories of inventors of yöre" başlı̆̆ıyla çevrilmiştir. Kaynak metinde yer alan çizimler, ilgili açılklamaların da çevrilmesiyle erek metinde de yer almıştır. Tarihsel olaylara dair anlatımlar farklı stratejiler kullanılarak çeviriye kazandırılmıştır. Karakterlerin meslekleri, konumları, sosyolojik bağları hakkında bilgi veren isimler de yine farklı stratejiler kullanılarak çevrilmiştir. Erek metnin hiçbir yerinde dipnota rastlanmazken kitapta çevirmen ön sözü de bulunmamaktadır. Kaynak metinde eserin giriş bölümünde yer alan Kuran ve İncil alıntısı çevirmen tarafından tekrar çevrilmemiş, Kuran çevirisi için Tarif Khalidi'nin İngilizce çevirisi, 1. Samuel'den alıntı için ise King James versiyonu tercih edilmiştir. Erek metinde yer alan isim ve tarihi olayların çevirisinde farklı çeviri stratejileri kullanılmakla birlikte, çoğunlukla açıklamaya yönelik stratejiler kullanılarak çevirilerde sözcüklerin biçim yönü yerine anlam yönü ön plana çıkmıştır.

\section{Kültürel öğelerin çevirisi}

Kültürel öğelerin çevirisi, çevirmenler için en meşakkatli çevirilerdir. Kaynak kültür ve erek kültür arasındaki farkllıklar ve bu farklılıkların derecesi çevirmeni farklı stratejilere yönlendirmektedir. $\mathrm{Bu}$ nedenle çeviri üzerine yapılan araştırmalar ve kuramsal yaklaşımlar da çeşitlilik göstermektedir. Bu yaklaşımların bazıları birbirinden çok farklı olmakla birlikte bazıları da benzerlikler göstermekte ya da birbirini çağrıştırmaktadır.

Bu kapsamda karşımıza çıkan isimlerden birisi İspanyol araştırmacı Javier Franco Aixela'dır (1996). Aixela, kültürel öğelerin çevirisinde karşllaşılan sorunların üstesinden gelebilmek için çevirmenlere bir dizi strateji sunar. Bu stratejileri iki temel başlık altında ele alır: Metinde yönlendirmeye daha az yer verilmesine yönelik yaklaşım Korunum5 (Conservation-değişikliğe kapalı yaklaşım) ve yönlendirici yönüyle ön plana çıan yaklaşım İkame (Substitution -yerine geçme sağlayan yaklaşım). Korunum kendi içinde tekrarlama (repetition- sözcük ödünç alma), ortografik uyarlama (orthographic adaptationtranskripsiyon yaparak çeviri), sözcüğü sözcüğüne çeviri (linguistic translation- kaynak metinde yer alan sözcügün gerçek anlamıyla çeviri), metin dışı açıklama (extratextual gloss- açıklama, dipnot kullanımı) ve metin içi açılama (intratextual gloss- metin içi açıklamalar, parantez kullanımı) olmak üzere beş farklı çeviri stratejisini içerir. İkame ise, eş anlamllhk (synonymy - kaynak metinde yer alan aynı kültürel sözcüklerin tekrarını önlemek için erek metinde benzer ya da eş anlamlı sözcüklerin kullanımı), sınırlı evrenselleştirme (limited universalization - kaynak kültüre ait bir öğenin erek kültüre yakın başka benzer bir öğeyle yer değiştirerek kullanılması), mutlak evrenselleştirme (absolute universalization - kaynak kültüre ait bir öğenin erek kültürde nötrleşmesi), yerlileşme (naturalization -

4 Türkiye Cumhuriyeti Kültür ve Turizm Bakanlığınca yürütülen ve kısa adı "TEDA" olan "Kültür ve Turizm Bakanlığı Türk Kültür, Sanat ve Edebiyat Eserlerinin Dışa Açılımını Destekleme Projesi”; Türk kültür, sanat ve edebiyatıyla ilgili Türkçede veya başka bir dilde yayımlanmış eserlerin, çeviri ve yayım marifetiyle yurt dışında tanıtılmasını sağlamak için yurt dışında veya yurt içinde faaliyet gösteren yayıncılara teşvik veren bir çeviri, yayım ve tanıtım destek programıdır.

5 Aksi belirtilmedikçe terim çevirileri tarafıma aittir. 
kaynak kültüre ait bir öğenin erek kültüre ait başka bir öğeyle yer değiştirmesi), silme (deletion - kaynak kültürde yer alan bir öğenin erek kültürde yer almasının engellenmesi), ve özerk yaratıcılk (autonomous creation - kaynak metinde yer almayan bir öğenin erek kültürde yer alması gerektiği düşünüldüğünde erek metinde yeni bir kültürel öğeye yer verilmesi) stratejilerinin kullanılmasıyla ilgilidir (Aixela, 1996, s.61-65). Aixela, çeviri stratejileriyle çevirmene çeviride kültürlerarası manipülasyona daha az ya da daha çok yer verebileceği bir yaklaşım sunmaktadır. Çevirmenin korunum yaklaşımı altında kullanacağı çeviri stratejileriyle kaynak metni daha ön plana çıkartan ve mümkün olduğunca kaynak metnin tam olarak aktarılması yönünde çabaya sahip olacağı söylenebilir. Diğer yandan ikame yaklaşımı altında sunulan çeviri stratejilerinin erek kültürü daha çok gözeten bir eğilim gösterdiği ileri sürülebilir. Bu çalışmada kaynak metin ve erek metin karşılaştırmasıyla çeviri stratejileri tespit edildikten sonra çevirmenin hangi yaklaşımı kullandığı da irdelenecektir. Çevirmeni bahsedildiği gibi zor duruma sokan kültürel çeviriler de kendi içinde gruplara ayrılabilir. Aixela bu gruplandırmanın iki sınıf olarak yapılabileceğini söyler: Özel isimler ve ortak ifadeler (Aixela, 1996, s 59). Bu çalışmada ortak ifadelerin çevirisine yer verilmeyecek, özel isimler ve çevirileri esas olarak inceleneceğinden özel isimlerin çevirisine yönelik kuramsal sorgulamalarla devam edilecektir.

\subsection{Kültürel öğeler bağlamında özel isimlerin çevirisi}

Kültüre özgü öğeler olarak özel isimlerin çevirisinde, kaynak metinde yer alan kültürel öğelerin sahip olduğu etkiyi erek metinde de oluşturmak ve kültürel farklılı̆̆ın üstesinden gelebilmek için çevirmen belirli çözümlere ihtiyaç duyar. Bu bağlamda özel isimlerin çevirisine yönelik çeşitli yaklaşımlar yer almaktadır. Bu yaklaşımlardan ilki çeviribilimci Theo Hermans'a aittir. Hermans, özel isimlerin çevirisini ikili bir kategoride sunmaktadır: olağan (conventional) ve yüklü (loaded). Olağan özel isimler kendilerine ait özel bir anlama sahip değildirler. Yüklü isimler ise çoğunlukla edebi metinlerde karşılaşılan ve metinde yer almasının özel bir nedenini barındıran isimlerdir. Bu isimler bir parça "ima edici" olmaktan belirgin bir şekilde "anlatımcı" olmaya kadar farklı derecelerde anlam yüklerine sahiptirler. Takma isimler de bu grup altında ele alınabilir. Kurgusal isimler olabilirken, özel bir kültür bağlamında belirli tarihsel ya da kültürel çağrışımlar çerçevesinde kurgusal olmayan isimler olarak da yer alabilirler. Belirli bir gelenek çerçevesinde ve önceden yapılmış çeviriler dışında (önemli toponomiler, tarihsel kurgu ya da kurgu olmayan isimler, aziz, kral v.b. isimler), günümüzde Olağan isimlerin çevirisinde, başlıca olarak tekrar etme, uyarlama ya da transkripsiyon olarak çevrilmeleri yönünde belirgin bir eğilim vardır. Yüklü isimler ise daha faza belirsizlik payına sahiptir, ancak sözcüğü sözcügüne (gerçek anlamıla ve kültürel olmayan çeviri) çeviriye doğru bir eğilime, anlatımcı yönlerini ortaya koyan bir yönelime sahiplermiş gibi görünürler (Hermans, 1988, s.13).

Başka bir yaklaşım ise araştırmacı Eirlys Davies'e ait. Davies, Aixela'nın sınıflandırmasından faydalanarak özel isimlerin çevirisi için - yedi farklı çeviri stratejisi sunar. Bunlardan ilki muhafazadır (Preservation). Bu stratejiye göre, Aixela'nın ödünç sözcük alma olarak bahsettiği stratejisinin benzeri olarak, erek kültürde bir karşılık yoksa sözcük ödünç alınabilmektedir. Dolayısıyla çevirmen kaynak metni korur. Ekleme (Addition) stratejisi ise Aixela'nın metin içi açılama tekniğine benzemektedir. Çeviride kaynak kültür korunur ancak gerekirse erek metne ekleme yapılabilir. Bu ekleme dipnotlar ya da metin içi açılamalar olarak karşımıza çıkabilir. Bu stratejinin tersi çıkartmadır (Omission). Çevirmen kaynak metindeki ifadeyi istediği gibi veremiyorsa çlkartmalar yapabilir. Bir diğer strateji küreselleştirme (Globalization), Aixela'nın sinırlı/mutlak evrenselleşme stratejileriyle benzerlik göstermektedir. Kaynak metindeki ifade erek metinde nötr hale getirilebilir ya da bu ifadeyle ilgili genelleme yapılabilir. Yerelleştirme (Localization ) ise kaynak metnin değişime uğraması anlamına gelir. Erek kültür göz önünde bulundurularak kaynak kültürdeki ifadeler değiştirilir. Bir diğer strateji 
A comparative analysis on proper names and their translation strategies in English translation of Kitab-ül Hiyel (The Book of Devices) by İhsan Oktay Anar / A. Araboğlu (pp. 699-708)

ise dönüştürme (Transformation), kültürel çevirinin küreselleştirme ve yerelleştirmenin ötesinde bir dönüşüme uğraması gerektiği zaman kullanılan bir stratejidir. Kaynak metindeki kültürel öğeler tamamen değişime uğrar. Son strateji olan yaratma (Creation) dahilinde çevirmen - erek metne kültüre özgü ifadeler ekleyebilir (Davies 2003, s 79-84).

Lincoln Ferndandes'in yaklaşımı ise (2016, s 44-57) on alt kategoriden oluşmaktadır. Bunlar ödünç alma (Rendition - sözcügü̈n ödünç alınması), kopya etme (Copy- sözcüğün birebir çevrilmesi), transkripsiyon (Transcription - sözcüğün transkripsiyon yapılarak çevrilmesi), yerine geçme (Substitution), yeniden sözcük türetme (Recreation), silme (Deletion- sözcüğün silinerek erek metinde yer almaması), ekleme (Addition - yeni bir sözcük eklenerek çeviri yapılması), yer değiştirme, (Transposition - sözcüğün erek metinde farklı bir dil bilgisel yapıyla yer değiştirmesi), fonolojik yer değişimi (Phonological Replacement - fonolojik olarak başka bir sözcükle yer değiştirme). Özel isimlerin çevirisi için birbirine benzer özellikler taşıyan birçok farklı yaklaşımdan daha söz edilebilir. Ancak bu çalışmanın sınırlılıkları kapsamında, kaynak metin ve erek metin karşılaştırması kapsamında incelenen özel isimlerin çevirilerinde kullanılan stratejilerin irdelenmesinde, açıklayıcı özelliği ve karşlaştırmayı belirli stratejiler çerçevesinde sunmak adına, Davies’in, Aixela'nın yaklaşımından geliştirdiği çeviri stratejileri ayrımı kullanılacaktır.

\section{5. İnceleme}

İhsan Oktay Anar'ın "Kitab-ül Hiyel, Eski Zaman Mucitlerinin İnanılmaz Hayat Öyküleri” adlı romanı ve Gregory Key tarafindan yapılan İngilizce çevrisi "The Book of Devices, The incredible life histories of inventors of yöre" de geçen özel isimler incelenerek Tablo 1'de karşlaştırmalı - olarak verilmiştir. İnceleme Davies'in, Aixela'nın kültürel çeviri stratejileri yaklaşımından geliştirdiği özel isimlerin çevirisine yönelik çeviri stratejileri kapsamında yapılmıştır. Özel isimlerin çevirisinde Davies’in sunduğu çeviri stratejilerinden Muhafaza, Ekleme ve Dönüştürme çeviri stratejilerinin kullanıldığı tespit edilmiştir. Diğer yandan çeviriler Aixela'nın sunduğu bakış açısıyla sözcüğü sözcüğüne çeviri, ortografik uyarlama, metin içi açıklama, sınırlı evrenselleştirme sınıflandırmasıyla da Tablo 1'de gösterilmiştir.

\subsection{Muhafaza / Ortografik Uyarlama}

Tablodaki örneklere bakıldığında kaynak metinde yer alan özel isimlerin çevirisi yapılırken, Davies’in muhafaza çeviri stratejisi ile çevirmen tarafından herhangi bir yönlendirme kullanılmadan kaynak metindeki kültürel ifade korunarak çeviri yapıldı̆̆ı görülmektedir. Aynı zamanda Aixela'nın yaklaşımıyla, kaynak metinde geçen kültürel öğenin, özel ismin transkripsiyonu yapılarak ortografik uyarlama gerçekleştirildiği söylenebilir. Kaynak metinde geçen kültürel sözcükler erek metinde de kültürel bir anlama sahip olduğundan kaynak kültürden ödünç alınan sözcük İngilizce yazılarak bir çeviri çözümü bulunmuştur.

Tablo 1. Çeviride kullanılan Muhafaza / Ortografik Uyarlama çeviri stratejisi örnekleri

\begin{tabular}{|l|l|l|l|}
\hline Kaynak Metin & Erek Metin & $\begin{array}{l}\text { Eirlys Davies } \\
\text { (2013) }\end{array}$ & $\begin{array}{l}\text { Javier } \\
\text { Aixela (1996) }\end{array}$ \\
\hline $\begin{array}{l}\text { Calûd } \\
\text { (Anar, 2018, s. 50) }\end{array}$ & $\begin{array}{l}\text { Calud } \\
\text { (Anar, 2018 (çev. Key, s.51)) }\end{array}$ & Muhafaza & Ortografik Uyarlama \\
\hline $\begin{array}{l}\text { Kurımî Hamdi Bey } \\
\text { (Anar, 2018, s 43.) }\end{array}$ & $\begin{array}{l}\text { Hamdi Bey the Crimean (Anar, } \\
\text { 2018 (çev. Key, s.42)) }\end{array}$ & Muhafaza & Ortografik Uyarlama \\
\hline
\end{tabular}




\begin{tabular}{|l|l|l|l|}
\hline $\begin{array}{l}\text { Ayn-1 Ekber Numan Efendi } \\
\text { (Anar, 2018, s.74) }\end{array}$ & $\begin{array}{l}\text { Ayn-1 Ekber Numan Effendi (Anar, } \\
\text { 2018 (çev. Key, s.68)) }\end{array}$ & Muhafaza & Ortografik Uyarlama \\
\hline $\begin{array}{l}\text { Abaza Haydar Efendi } \\
\text { (Anar, 2018, s81.) }\end{array}$ & $\begin{array}{l}\text { Haydar Effendi the Abazin (Anar, } \\
\text { 2018 (çev. Key, s.74)) }\end{array}$ & Muhafaza & Ortografik Uyarlama \\
\hline $\begin{array}{l}\text { Ânî Murtaza Efendi } \\
\text { (Anar, 2018, s.86) }\end{array}$ & $\begin{array}{l}\text { Ani Murtaza Effendi (Anar, 2018 } \\
\text { (çev. Key, s.78)) }\end{array}$ & Muhafaza & Ortografik Uyarlama \\
\hline $\begin{array}{l}\text { Teke Abbas Efendi } \\
\text { (Anar, 2018, s87.) }\end{array}$ & $\begin{array}{l}\text { Teke Abbas Effendi (Anar, 2018 } \\
\text { (çev. Key, s.80)) }\end{array}$ & Muhafaza & Ortografik Uyarlama \\
\hline $\begin{array}{l}\text { Sivaslı Ali Nazik Efendi } \\
\text { (Anar, 2018, s.122) }\end{array}$ & $\begin{array}{l}\text { Ali Nazik Effendi of Sivas (Anar, } \\
\text { 2018 (çev. Key, s.109)) }\end{array}$ & Muhafaza & Ortografik Uyarlama \\
\hline $\begin{array}{l}\text { Laz Beşir Efendi (Anar, } \\
\text { 2018, s.137) }\end{array}$ & $\begin{array}{l}\text { Laz Beşir Effendi (Anar, 2018 (çev. } \\
\text { Key, s.121)) }\end{array}$ & Muhafaza & Ortografik Uyarlama \\
\hline $\begin{array}{l}\text { Tatar Mercan Efendi (Anar, } \\
\text { 2018, s. 142) }\end{array}$ & $\begin{array}{l}\text { Mercan Effendi the Tatar (Anar, } \\
\text { 2018 (çev. Key, s.51)) }\end{array}$ & Muhafaza & Ortografik Uyarlama \\
\hline $\begin{array}{l}\text { Lamiî Çelebi (Anar, 2018, s. s. } \\
\text { 148) }\end{array}$ & $\begin{array}{l}\text { Lamii Chelebi (Anar, 2018 (çev. } \\
\text { Key, s.131)) }\end{array}$ & Muhafaza & Ortografik Uyarlama \\
\hline
\end{tabular}

\subsection{Muhafaza / Sözcüğ̈̈ Sözcü̆̆̈̈ne Çeviri}

Metinde en çok kullanılan çeviri stratejilerinin muhafaza ve sözcüğü sözcüğüne çeviri olduğu söylenebilir. Kaynak metinde yer alan kültürel öğeler olarak özel isimler Muhafaza stratejisiyle çevirmen tarafından herhangi bir yönlendirmeye uğramamış ve aynı zamanda özel isimleri oluşturan sözcüklerin (karakterlerin mesleklerini, toplumsal konumlarını, fiziksel özellikleriyle ilgili benzetmeleri, hısım ilişkilerini gösteren) çevirileri sözcüğü sözcüğüne çeviri ile doğrudan çeviri yöntemiyle yapılmıştır. Kaynak metindeki kültürel ifadeler sözlük anlamlarıyla çevrilmiştir.

Tablo 2. Çeviride kullanılan Muhafaza / Sözcüğü Sözcüğüne Çeviri stratejisi örnekleri

\begin{tabular}{|c|c|c|c|c|}
\hline Kaynak Metin & Erek Metin & $\begin{array}{l}\text { Eirlys Davies } \\
(2013)\end{array}$ & $\begin{array}{l}\text { Javier F } \\
\text { (1996) }\end{array}$ & nco Aixela \\
\hline $\begin{array}{l}\text { Çeşm-i Badem Ceylan } \\
\text { Hatun (Anar, 2018, s. 73) }\end{array}$ & $\begin{array}{l}\text { Lady Ceylan the Almond-Eyed } \\
\text { (Anar, } 2018 \text { (çev. Key, s.67)) }\end{array}$ & Muhafaza & $\begin{array}{l}\text { Sözcüğü } \\
\text { Çeviri }\end{array}$ & Sözcüğüne \\
\hline $\begin{array}{l}\text { Aynacı Zihni Dede (Anar, } \\
\text { 2018, s. 74) }\end{array}$ & $\begin{array}{l}\text { Zihni Dede the Huckster (Anar, } \\
2018 \text { (çev. Key, s.67)) }\end{array}$ & Muhafaza & $\begin{array}{l}\text { Sözcüğ̈̈ } \\
\text { Çeviri }\end{array}$ & Sözcüğüne \\
\hline $\begin{array}{l}\text { Kokarca Fikri Bey (Anar, } \\
\text { 2018, s.74) }\end{array}$ & $\begin{array}{l}\text { Fikri Bey the Polecat (Anar, } 2018 \\
\text { (çev. Key, s.67)) }\end{array}$ & Muhafaza & $\begin{array}{l}\text { Sözcüğü } \\
\text { Çeviri }\end{array}$ & Sözcüğüne \\
\hline $\begin{array}{l}\text { Çapraz Cafer Efendi (Anar, } \\
\text { 2018, s. 74) }\end{array}$ & $\begin{array}{l}\text { Contrary Cafer Effendi (Anar, } 2018 \\
\text { (çev. Key, s.68)) }\end{array}$ & Muhafaza & $\begin{array}{l}\text { Sözcüğü } \\
\text { Çeviri }\end{array}$ & Sözcüğüne \\
\hline $\begin{array}{l}\text { Sinobî Bülbül Dede } \\
\text { Hazretleri (Anar, 2018, s.) }\end{array}$ & $\begin{array}{l}\text { His Excellency Nightingale Dede } \\
\text { the Sinopian (Anar, } 2018 \text { (çev. Key, } \\
\text { s68)) }\end{array}$ & Muhafaza & $\begin{array}{l}\text { Sözcüğ̈̈ } \\
\text { Çeviri }\end{array}$ & Sözcüğüne \\
\hline $\begin{array}{l}\text { Divane Salim Efendi (Anar, } \\
\text { 2018, s 80.) }\end{array}$ & $\begin{array}{l}\text { Mad Salim Effendi (Anar, } 2018 \\
\text { (çev. Key, s.73)) }\end{array}$ & Muhafaza & $\begin{array}{l}\text { Sözcüğü } \\
\text { Çeviri }\end{array}$ & Sözcüğüne \\
\hline $\begin{array}{l}\text { Çeşm-i Yek Tayyar Bey } \\
\text { (Anar, 2018, s 81.) }\end{array}$ & $\begin{array}{l}\text { One-Eyed Tayyar Bey (Anar, } 2018 \\
\text { (çev. Key, s.74) ) }\end{array}$ & Muhafaza & $\begin{array}{l}\text { Sözcüğ̈̈ } \\
\text { Çeviri }\end{array}$ & Sözcüğüne \\
\hline $\begin{array}{l}\text { Leblebici Kıl Hüsrev Bey } \\
\text { (Anar, 2018, s 86.) }\end{array}$ & $\begin{array}{l}\text { Bristly Hüsrev Bey the chickpea } \\
\text { monger (Anar, } 2018 \text { (çev. Key, } \\
\text { s.78)) }\end{array}$ & Muhafaza & $\begin{array}{l}\text { Sözcüğü } \\
\text { Çeviri }\end{array}$ & Sözcüğüne \\
\hline
\end{tabular}


A comparative analysis on proper names and their translation strategies in English translation of Kitab-ül Hiyel (The Book of Devices) by İhsan Oktay Anar / A. Araboğlu (pp. 699-708)

\begin{tabular}{|c|c|c|c|c|}
\hline $\begin{array}{l}\text { Topuzbaş Cuma Paşazade } \\
\text { Tavşancı Mikail Efendi } \\
(\text { Anar, 2018, s. 84) }\end{array}$ & $\begin{array}{l}\text { Mikhail Effendi the Haremonger, } \\
\text { Son of Macehead Cuma Pasha } \\
\text { (Anar, } 2018 \text { (çev. Key, s.79)) }\end{array}$ & Muhafaza & $\begin{array}{l}\text { Sözcüğü } \\
\text { Çeviri }\end{array}$ & Sözcüğüne \\
\hline $\begin{array}{l}\text { Şaşı Kamil Bey (Anar, 2018, } \\
\text { s. 87) }\end{array}$ & $\begin{array}{l}\text { Cross-Eyed Kamil Bey (Anar, } 2018 \\
\text { (çev. Key, s.79)) }\end{array}$ & Muh & $\begin{array}{l}\text { Sözcüğü } \\
\text { Çeviri }\end{array}$ & Sözc \\
\hline $\begin{array}{l}\text { Buzağızade Maymun İlham } \\
\text { Efendi (Anar, 2018, s. 112) }\end{array}$ & $\begin{array}{l}\text { Monkey İlham Effendi Son of the } \\
\text { Calf (Anar, } 2018 \text { (çev. Key, s.101)) }\end{array}$ & Muh & $\begin{array}{l}\text { Sözcüğü } \\
\text { Çeviri }\end{array}$ & Sözcüğüne \\
\hline $\begin{array}{l}\text { Yusrizade tokatçı Kevakib } \\
\text { Efendi (Anar, 2018, s.127) }\end{array}$ & $\begin{array}{l}\text { Slaphappy Kevakib Effendi Son of } \\
\text { Yusri (Anar, } 2018 \text { (çev. Key, s.113)) }\end{array}$ & Muhafaza & $\begin{array}{l}\text { Sözcüğü } \\
\text { Çeviri }\end{array}$ & Sözcüğüne \\
\hline $\begin{array}{l}\text { Çeşm-i Siyah Badem Efendi } \\
\text { (Anar, 2018, s. 127) }\end{array}$ & $\begin{array}{l}\text { Dark-Eyed Almond Effendi (Anar, } \\
2018 \text { (çev. Key, s.113)) }\end{array}$ & Muhafaza & $\begin{array}{l}\text { Sözcüğü } \\
\text { Çeviri }\end{array}$ & Sözcüğüne \\
\hline $\begin{array}{l}\text { Tamburlu } \\
\text { eşrafından } \\
\text { Efendi ile Tivane }\end{array}$ & $\begin{array}{l}\text { Mad Salim Effendi and Fülfül } \\
\text { Chelebi, of the notables of } \\
\text { Tamburlu coffeehouse (Anar, } 2018 \\
\text { (çev. Key, s.131)) }\end{array}$ & Muhafaza & $\begin{array}{l}\text { Sözcüğü } \\
\text { Çeviri }\end{array}$ & Sözcüğüne \\
\hline $\begin{array}{l}\text { Kuyruklu Abidin Çavuş } \\
\text { (Anar, 2018, s. 133) }\end{array}$ & $\begin{array}{l}\text { Tall-Tale Sergeant Abidin (Anar, } \\
2018 \text { (çev. Key, s.116) ) }\end{array}$ & Muhafaza & $\begin{array}{l}\text { Sözcüğü } \\
\text { Çeviri }\end{array}$ & Sözcüğüne \\
\hline
\end{tabular}

\section{5•3. Dönüştürme / Sintrh Evrenselleştirme}

Tablo 3’te ise dönüştürme çeviri stratejisiyle yapılan çeviride, çevirmen kaynak kültürde yer alan sözcüğü erek kültürde anlamlı bir çözüm haline getirebilmek için dönüştürmüştür. Kaynak metinde yer alan sözcüğü bırakıp yerine onunla ilgili, ona benzeyen başka bir sözcük seçmiştir. Sintrh evrenselleștirme çerçevesinde, çevirmen kaynak kültüre ait öğeyi erek kültüre ait başka bir öğeyle karşılamış, aldığı karar çerçevesinde ve yorum yaparak erek metinde erek okur tarafından daha bilindik bir sözcük tercih etmiştir.

Tablo 3. Çeviride kullanılan Dönüştürme / Sözcüğü Sözcüğüne Çeviri stratejisi örneği

\begin{tabular}{|l|l|l|l|}
\hline Kaynak Metin & Erek Metin & $\begin{array}{l}\text { Eirlys Davies } \\
\text { (2013) }\end{array}$ & $\begin{array}{l}\text { Javier } \\
\text { Aixela (1996) }\end{array}$ \\
\hline $\begin{array}{l}\text { Siyahî Haydar Çelebi } \\
\text { (Anar, 2018, s.80) }\end{array}$ & $\begin{array}{l}\text { Haydar Chelebi Effendi the Negro } \\
\text { (Anar, 2018 (çev. Key, s.73)) }\end{array}$ & Dönüştürme & $\begin{array}{l}\text { Sözcüğü Sözcüğüne } \\
\text { Çeviri }\end{array}$ \\
\hline
\end{tabular}

\subsection{Ekleme / Metin İçi Açıklama}

Çevirmen kaynak metinde geçen kültürel ifadeye yeni bir sözcük ekleyerek ekleme çeviri stratejisiyle bileşik bir sözcük türetmiş, kaynak metindeki anlamın dışına çıkmıştır. Ancak kaynak metindeki kültürel ifadenin yerine yeni bir ifade ile anlam karşılanmıştır. Metin içi açıklama ile anlamın genişletildiği görülmektedir.

Tablo 4'te yer alan ikinci örnek ise özel isim çevirisi olmasa da çevirmenin kaynak metni mümkün olduğunca anlaşılır şekilde çevirme amacı güttüğünü gösteren önemli bir örnek olması sebebiyle bu çalışmada tablo olarak yer almıştır. Çevirmen daha önce kullandığı muhafaza çeviri stratejisini kullanmaya devam etseydi muhtemelen erek okur "besmele" sözcüğünün anlamını hiçbir şekilde anlamayacaktı. Çevirmen bunun yerine sözcüğün ne anlama geldiğini metin içinde açıklamayı tercih etmiştir. 
Tablo 4. Çeviride kullanılan Ekleme / Metin İçi Açıklama çeviri stratejisi örnekleri

\begin{tabular}{|l|l|l|l|}
\hline Kaynak Metin & Erek Metin & $\begin{array}{l}\text { Eirlys Davies } \\
\text { (2013) }\end{array}$ & $\begin{array}{l}\text { Javier Franco Aixela } \\
\text { (1996) }\end{array}$ \\
\hline $\begin{array}{l}\text { Çakmak Tayyar Paşa (Anar, } \\
\text { 2018, s. 74) }\end{array}$ & $\begin{array}{l}\text { Flinstone Tayyar Pasha (Anar, } \\
\text { 2018 (çev. Key, s.68)) }\end{array}$ & Ekleme & Metin İçi Açıllama \\
\hline $\begin{array}{l}\text { Sonunda ezan okunmaya } \\
\text { başladığında kaşılar } \\
\text { besmeleyle tencerelere } \\
\text { uzanıverdi. (Anar, 2018, } \\
\text { s.144) }\end{array}$ & $\begin{array}{l}\text { At last, when the azan } \\
\text { comenced, spoons whent out } \\
\text { bismillahirrahmanirrahim. } \\
\text { (Anar, 2018 (çev. Key, s.127)) }\end{array}$ & Ekleme & Metin İçi Açlklama \\
\hline
\end{tabular}

Özel isimlerin çevirisinin yanı sıra, anlatımın önemli bir parçası olan, icatların çizimlerinin adlarının ve altında yer alan açıklamaların da muhafaza ve sözcüğü sözcüğüne çeviri stratejileriyle yapıldığı görülmektedir. Eserde yer alan görsellerin çevirisinde kullanılan stratejilerin de genel çeviri eğilimini tespit etmede katkısı olacağı düşünüldüğünden bu çeviri karşılaştırmasına da bakmakta fayda vardır.

Tablo 5. İcatların çizimlerinin adlarının ve altında yer alan açıklamalarının çevirilerinde kullanılan çeviri stratejilerine yönelik örnekler

\begin{tabular}{|l|l|l|l|}
\hline Kaynak Metin & Erek Metin & $\begin{array}{l}\text { Eirlys Davies } \\
\text { (2013) }\end{array}$ & $\begin{array}{l}\text { Javier Franco } \\
\text { Aixela (1996) }\end{array}$ \\
\hline $\begin{array}{l}\text { Yâfes Çelebi'nin Debbâbesi } \\
\text { (Anar, 2018, s.21) }\end{array}$ & $\begin{array}{l}\text { Yafes Chelebi’s Dabbaba(Anar, } \\
\text { 2018 (çev. Key, s.20)) }\end{array}$ & Muhafaza & Ortografik Uyarlama \\
\hline $\begin{array}{l}\text { Düşahî ve palanketesi (Anar, } \\
\text { 2018, s31.) }\end{array}$ & $\begin{array}{l}\text { Düşahi and Chain-shot (Anar, } \\
\text { 2018 (çev. Key, s.31)9 }\end{array}$ & Muhafaza & $\begin{array}{l}\text { Sözcüğü Sözcüğüne } \\
\text { Çeviri }\end{array}$ \\
\hline Münfelik (Anar, 2018, s.56) & $\begin{array}{l}\text { Münfelik (Anar, 2018 (çev. Key, } \\
\text { s44)) }\end{array}$ & Muhafaza & $\begin{array}{l}\text { Sözcüğü Sözcüğüne } \\
\text { Çeviri }\end{array}$ \\
\hline $\begin{array}{l}\text { Tahtelbahirin suya dalma ve } \\
\text { çlkma sistemi (Anar, 2018, } \\
\text { s.57) }\end{array}$ & $\begin{array}{l}\text { Submersion and Surfacing System } \\
\text { of The Submarine Vessel (Anar, } \\
\text { 2018 (çev. Key, s.49)) }\end{array}$ & Muhafaza & $\begin{array}{l}\text { Sözcüğü Sözcüğüne } \\
\text { Çeviri }\end{array}$ \\
\hline $\begin{array}{l}\text { Varlığa gelip yok olan bir } \\
\text { taşla çalş̧abilecek iki zamanlı } \\
\text { devri daim makinası (Anar, } \\
\text { 2018, s.) }\end{array}$ & $\begin{array}{l}\text { Two-Stroke Perpetual Motion } \\
\text { Machine Powered by a stone that } \\
\text { appears and disappears (Anar, } \\
\text { 2018 (çev. Key, s.136)) }\end{array}$ & Muhafaza & $\begin{array}{l}\text { Sözcüğü Sçzeviri } \\
\text { Çü̆üne }\end{array}$ \\
\hline
\end{tabular}

\section{Sonuç}

TEDA projesi desteğiyle Binghamton Üniversitesi Türk Dili Profesörü Gregory Key tarafından İngilizceye çevrilen "The Book of Devices, The incredible life histories of inventors of yöre"'de geçen kültürel öğeler bağlamında özel isimlerin çevirisi incelendiğinde, Davies’in sınıflandırmasıyla, çoğunlukla Muhafaza çeviri stratejisinin ve Aixela'nın sözünü ettiği Sözcüğü Sözcüğüne Çeviri yönteminin kullanıldığı görülmektedir. Çevirmenin kaynak metinde geçen kültürel ifadeleri mümkün olduğunca korumaya çalıştığı, bunu sözcüğü sözcüğüne çeviri yaparak sağladığı söylenebilir.

Metinde geçen özel isimler incelendiğinde, Theo Hermans'ın özel isimlerin metindeki görevleri ve çevirilerine yönelik sunduğu olağan ve yüklü başlıklı ikili kategoride ele alınan yaklaşımına göre, çalışmanın konusunu oluşturan özel isimler yüklü yaklaşım altında değerlendirilebilir. Bu isimlerin hepsinin metinde yer almasının bir nedeni bulunmaktadır. İsimlerin büyük bir kısmı metinde geçen olayları tarihsel bir anlatımla süslemek maksadıyla aktaran olarak görev almaktadır. Aktaranların özellikleri, meslekleri ya da fiziksel görünümleri isimlerinin oluşturulmasını sağlamakta, bu sayede aktaran kişi okur açısından daha inandırıcı bir konuma gelmektedir denebilir. Tarihsel ve kültürel 
A comparative analysis on proper names and their translation strategies in English translation of Kitab-ül Hiyel (The Book of Devices) by İhsan Oktay Anar / A. Araboğlu (pp. 699-708)

çağrışımlarla kaynak metinde yer alan bu isimlerin çoğunlukla anlamın korunarak çevrilmesinin sebebi, çevirmenin kaynak metindeki kültürel anlamı erek kültüre eksiksiz taşıma kaygısı olabilir.

Aixela'nın kültürel öğelerin çevirisinde karşılaşılan sorunların üstesinden gelebilmek için sunduğu ve korunum ve ikame olmak üzere çeviri stratejilerini iki ana başlık altında topladığı ikili kategoriye göre ise, çevirmenin çoğunlukla korunum yaklaşımını tercih ettiği söylenebilir. Metinde çevirmenin erek okurun kültürel ifadeleri daha iyi anlamasına yönelik yönlendirici çeviri stratejileri kullanmadığı görülmektedir. Metnin neredeyse tamamında yer alan ve doksandan fazla farklı özel isim kullanılarak oluşturulan tarihsel ve kurgusal bu anlatının, baştan sonra kültürel çeviri özellikleri taşıdığı ve her özel isim çevirisinin zorlu bir kültürel çeviri sürecinin parçası olduğu görülmektedir. Bu bağlamda, çevirmenin genel çeviri eğiliminin kaynak odaklı olduğu söylenebilir. Çevirmen özel isimleri çoğunlukla sözlük anlamlarıyla çevirerek kaynak metnin anlamını korumaya çalışmıştır. Diğer yandan çevirinin erek okur için yapıldığı göz önünde bulundurulduğunda, erek okurun, kaynak odaklı çeviri metnini kaynak kültürün bakış açısıyla anlamakta zorluk yaşayabileceği söylenebilir.

\section{Kaynaklar}

Aixela, J. F. (1996). Culture-Specific Items in Translation. Translation, Power, Subversion, Alvarez, R. and Carmen-Africa Vidal, M (eds.). Clevedon: Multilingual Matters. (s 52-78).

Aktulum, K. (1999). Metinlerarası İlişkiler. Ankara : Öteki.

Anar, İ. O. (2018). Kitab-ül Hiyel, Eski Zaman Mucitlerinin İnanılmaz Hayat Öyküleri. İstanbul: İletişim.

Anar, İ. O.. (2018). The Book of Devices, The incredible life histories of inventors of yöre. (Çev.) Gregory Key. İstanbul: Koç Üniversitesi.

Davies, E. (2003). A Goblin or a Dirty Nose? The Treatment of Culture-specific References in Translations of Harry Potter. The Translator 6, (s 65-100).

Fernandes, L. (2006). "Translation of Names in Children's Fantasy Literature: Bringing the young reader into play." New Voices in Translation Studies. 2 (s. 44-57)

Hermans, T. (1988) "On Translating Proper Names, with reference to De Witte and Max Havelaar", London/Atlantic Highlands: The Athlone Press

Şengül, S. (2018). Yeni Tarihselcilik Örneği Olarak Kitab-ül Hiyel'de Tarihi Unsurlar. Dede Korkut Uluslararası Türk Dili ve Edebiyatı Araştırmaları Dergisi, 7/ 16, s. 90-103. 